\title{
The Contentious Politics of Nationalism and the Anti-Naturalization Campaign in Tunisia, 1932-33
}

\section{Introduction}

The aim of this article is to investigate how, when, and why people came to mobilize en masse in the name of a Tunisian nation. Proceeding from the foundational contention that nationalism, and particularly anti-colonial nationalist mobilization, is not an inevitable and otherwise uninteresting political phenomenon attributable to colonialism itself (Lawrence 2013), I look to analyse nationalism as a form of contentious politics (McAdam et al. 2001), the dynamics of which must be explained. In understanding nationalism as a form of contention, I take lessons, too, from more recent trends in the study of nationalism that see national identity not simply as a byproduct of modernity but as a shifting, changeable, and polyvalent phenomenon that only occasionally finds expression in significant social action. Two principal questions, then, motivate this study. Firstly how, why, and through what mechanisms and means, did mobilization in the name of the nation emerge as an organizing rubric for mass collective action in Tunisia? Secondly, and relatedly, what importance can we attribute to the modalities of collective action itself for the construction of national imaginaries and the conduct of nationalist politics at an elite level? For these purposes, I will argue, the anti-naturalization campaign in Tunisia provides us with an intriguing case study.

In what follows, the first section is devoted to a consideration of extant theoretical perspectives on the study of nationalism, Tunisian nationalism in particular, and the position of the present study within these literatures. Analysis of the anti-naturalization campaign itself proceeds in two parts. In a first section, I provide a detailed account of the anti-naturalization campaign and how its emergence must be viewed in light of the particularities of the political field in Protectorate Tunisia. In a second section, I ask what importance we can attribute to such instances of mass-level collective action in the formation of national collective imaginaries and provide an account of the consequences of such episodes for elite-level politics itself. Overall, the claim made in what follows is that nationalism in Tunisia, as a broad-based phenomenon, can only be understood by looking closely at the dynamics of contentious politics witnessed in the interwar period. At stake here is a process-relational ontology that is both agentic and eventful. Rather than as an emanation of larger macro-social developments, it is argued, Tunisian 
nationalism unfolded in the redoubts and trenches of contentious street-level mobilization. In order to understand the form it took, attention needs to be paid to the contingent logics of a particular contentious event that had causal significance for the subsequent conduct of nationalist politics and effected a lasting boundary between Tunisians and non-Tunisians that was articulated along religio-political lines.

\section{Theoretical Overview: Nationalism as Contention}

For a long time, the study of nationalism as a phenomenon was dominated by macro-level analysis of large-scale social transformations seen to be productive of forms of national identification. Thus, in a 'developmentalist (Brubaker 1996: 19)' mould, major theorists of nationalism such as Ernest Gellner (1983) and Benedict Anderson (1991) sought out the structural changes necessary for such solidarities to emerge. In these readings, nationalism is a distinctly modern phenomenon attributable to broader socioeconomic forces, whether this be industrialization in Gellner's account or, in Anderson's case, the particular forms of 'imagined community' made possible by the emergence of 'print capitalism'. However, by associating nationalism with a certain stage of social, economic or political development, nationalism risked becoming hypostatized as an accretion of modernity, a form of identity explainable according to unilinear, isomorphic and teleological understandings of development. What is missing from these causal stories is an empirical account or explanation of why people identify with the nation (and not some other grouping) and, recognizing that not all nations and nationalisms are alike, why national identities take the particular forms that they do. Related to this criticism is the observation that if, as Gellner recommends, nationalism in general is intimately related to industrialization and the societal forms to which it gives birth, analysis of nationalism operating on this level nonetheless stops short of adducing 'mechanism[s] tying broad social forces to concrete human action (Beissinger 1998: 170)'.1

In what follows, I argue that for the purposes of this study nationalism should be conceived as a form of contentious politics. That is, it is a form of 'politics in which states vie with societal actors or with other states for control over a certain set of political objects: over the crystallisation of the state's physical, human or cultural boundaries (Beissinger 1998: 174)'. Further, nationalism, or nationalist action, is seen not as 'an isolated contingent event, but rather 
a chain of connected contingent events which assume a larger pattern and meaning (ibid.)'.

Overall, adopting a contentious politics framework means understanding nationalism, as the authors of Dynamics of Contention suggest, as 'part of struggle (McAdam et al. 2001, 227)'. This means that any episode of sustained collective contentious activity should not be understood 'as the expression of any single discourse, ideology, or nominally distinct form of contention (ibid.)'. Instead, we should look to how relations between 'varied political sources' might 'converge in nationalist outcomes (ibid.)'.

This move is informed by, and closely aligned with, more recent trends in the study of nationalism, race, and ethnicity. Process-oriented studies take the specific form and timing of 'nationalist' social action as the variables to be explained and see identities as subject to considerable change (Brubaker 2004; Calhoun 1997; Wimmer 2013). Other accounts taking anticolonial nationalism as the specific focus will similarly argue that "the nation-itself' does not exist separately, transhistorically, in any ontological sense, from ... contests over representation (McDougall 2006: 10)' and 'nationalism is best seen as a relational identity (Duara 1995: 15)'. The earlier work of Fredrik Barth (1969) provides some intellectual backdrop to these approaches. Seeing national identifications as inherently fickle and fluid allegiances subject to change over time, the task in Barth's analysis was to explain why certain signifiers and elements of shared culture, or what he referred to as 'cultural stuff', became salient at certain conjunctures and came to direct social action by contributing to the creation of 'ethnic boundaries'. This meant recognizing, too, that cultural differences were not 'primary and definitional characteristics' but 'social identifiers which are the result, the product, of struggles in the first place (McCrone 1998: 28)'. It was in and through such struggles, scholars came to recognize, that changes in feelings of 'groupness (Brubaker 2004)' could be produced rapidly over short periods of time.

Within the field of nationalism studies, Rogers Brubaker's (1996) call for what he terms, after Sewell (1996), an 'eventful' approach to the study of nationhood and nationalism is predicated on this recognition that people may, as a result of particular conjunctures and transformative events, come very suddenly to speak in the name of the nation and advance nationalist claims. Building on Brubaker's insights, Mark Beissinger has done most to link up the disciplines of nationalism studies and contentious politics in his (2002) study of nationalist mobilization in the former USSR. The most crucial of Beissinger's interventions concerns the so-called 'thought-to- 
action paradigm (2002: 10)'. By calling for a renewed focus on contentious politics, Beissinger helps overcome hoary questions surrounding the transition from thought to action. By implication, we are not asking whether generalized feelings of national identification precede action. Rather, recognizing that people rarely act according to shared, uniform and collective understandings and agendas, focus is shifted to the dynamics of contentious events themselves. Seen through this lens, identities are not pregiven constructs but may be 'defined in the context of agency' and nationalism itself should be seen as 'both a structured and structuring phenomenon (ibid.: 9)'. In other words, it is in the contentious event as a privileged domain of action that we may best be able to see how and why people begin to act and speak in the name of (a certain version of) the nation.

By foregrounding a particular contentious episode, the approach adopted in this study therefore articulates with these more recent trends in the study of nationalism that stress the processual, relational and eventful dynamics of ethnicity and nationalism. The anti-naturalization campaign did not begin as a self-consciously nationalist uprising. It was in and through this episode, however, that Islam and the Muslim identity of the Tunisian nation came to be valorized as objects of struggle in the eventual service of a broader nationalist campaign. The aim in what follows, then, is to highlight how, through a particular contentious event, aspects of the nation become salient as mobilizing rubrics and various forms of contention concatenate to produce nationalist outcomes.

\section{Anti-Colonial Nationalism and Tunisia}

By paying attention to the 'contingent features and causal significance (McAdam \& Sewell 2001: 101)' of a particular contentious event, the approach adopted here also marks a departure from previously dominant modes of understanding anti-colonial nationalism. While 'developmentalist' understandings of nationalism risked teleology, so-called 'evolutionary' perspectives on anti-colonial nationalism similarly saw mass anti-colonial action in the name of the nation as an awakening and inevitable stage to be reached (Duara 1995; cf. Burke 1998, Cooper 2005). More recently, some of the trends in the study of ethnicity, race and nation identified above have found their way into the study of anti-colonial nationalism wherein we see a shift away from analysis operating in the mode of intellectual history toward an explicit focus 
on the movement dynamics and contentious politics of nationalism in the colonized world (e.g. Aminzade 2013; Lawrence 2013; Wyrtzen 2013, 2015).

Of the scholarship available on Tunisian nationalism, much was written before any historical and sociological work on the constructed and contested nature of nations and nationalism. The elite-level focus of much of this literature calls to mind James Gelvin's criticisms of the study of Arab Nationalism; a phenomenon, he argues, that, following the lead of such preeminent figures as Albert Hourani and George Antonius, was understood essentially according to 'the activities of a small elite (1998: 7)'. Furthermore, a focus on the purported 'origins' of Tunisian nationalism leads to an erroneous reading of history. Indeed, by referring to an overall category of 'Tunisian nationalism' or to a Tunisian 'national movement', one risks subsuming all instances of oppositional activity within a nationalist frame. ${ }^{2}$ The task, then, is to avoid teleological understandings of nationalism that link together all instances of oppositional activity in colonial societies as examples of 'proto-nationalism' or as early and 'immature' forms of nationalist activity. ${ }^{3}$ This is not to say that such forms of opposition are not linked. It is, however, to argue that such overarching understandings elide questions of significant importance that relate to shifts from one mode of articulating and conducting 'nationalist' politics to another.

For our purposes, this shift might be identified with what Miroslav Hroch (1985) termed 'Phase C' of nationalism wherein mass popular national movements emerge. Most accounts of nationalism in Tunisia agree in identifying three principal stages of 'nationalist' activity associated with three separate groupings; namely, the 'Young Tunisians', the 'Destour', and the 'Neo-Destour'. It is only with the emergence of the Neo-Destour and Habib Bourguiba that nationalism becomes a mass-based phenomenon, however (Anderson 1987: 167ff.; Brown 1964: 3-6; Julien 1952: 73-6; Perkins 2014: 101-3; Rivlin 1952: 170-1). The emergence of such forms of national-level popular politics is what is problematized in the account that follows and is not seen simply as, in Beissinger's words, 'an externalization of nationalist ways of thinking brought into being well before the onset of nationalist action (2002: 9)'. Indeed, the argument advanced in this study holds firstly that mass-level action in the name of a nation does not flow automatically from nationalist ways of thinking and, secondly, that nationalism was never a coherent and cohesive phenomenon but a domain in which various forms of contentious politics were played out. 


\section{The Anti-Naturalization Campaign}

The outbreak of the anti-naturalization campaign can only be understood in the context of a political field in which national identity and notions of sovereignty were ambiguous and constituted potential targets of political claims. Mary Lewis, in her recent (2014) Divided Rule, has made a timely intervention into the development of the French Protectorate in Tunisia. Taking lessons from the new imperial history and eschewing binary understandings of colonizer and colonized, Lewis argues that the political field in Tunisia was for a long time highly unsettled. The original justification for a French presence in Tunisia was as a protector of the bey's sovereignty and, unlike in neighbouring Algeria, the French Protectorate was never built on annexationist designs. Further, the Bardo and La Marsa treaties of 1881 and 1883 meant honouring existing treaties between the bey and countries such as Italy and Great Britain. As a result, the French authorities came to be confronted by a situation in which multiple nationalities existed within the same territory and were subject to competing sovereign jurisdictions.

Ultimately, Lewis convincingly argues, it was partly with the aim of ending forms of 'extraterritorial sovereignty' that the French Protectorate announced, in 1914, a specific 'Tunisian nationality' for all Muslims and Jews with a claim to heritage in Tunisia and, over time, came to advance the principle of 'cosovereignty' over 'protection' (Lewis 2014: chap. 4). This did not mean, however, that the questions of Tunisian nationality and the sovereign domain of the bey were settled. Indeed, conflicts continued to play out over the sovereign status of habūs land ${ }^{4}$ and while religious affairs fell under the bey's jurisdiction, this did not stop French authorities from trying to influence appointments and decision-making

For our purposes, what matters most is that notions of Tunisian nationality and sovereignty were both ambiguous and contested; a fact that, as Lewis herself notes, 'lay at the heart (2014: 167)' of subsequent conflicts, including the anti-naturalization campaign. This fact is perhaps best illustrated by way of contrast, namely with neighbouring Algeria. French sovereignty over Algeria, a region that had been formally annexed, brooked no ambiguity. Furthermore, the centralization and bureaucratization of traditional justice systems, as well as their subordination to the sovereign French courts, meant that the location of ultimate jurisdictional authority was not in doubt (Lewis 2009: 140-1). In Tunisia, however, where sovereignty remained nominally in 
the hands of the bey and where competing nationalities existed outside an overall framework of assimilation and integration, naturalization proposals were contested on markedly different terms. Further, as Carmel Sammut writes, 'the beylical State served as a point of reference' and made it possible to frame grievances in terms of a 'national community threatened by a foreign presence $(1977,204) '$. In short, nationality was not only up for grabs as an administrative category but it could also constitute the basis for political claims.

Protest in Tunisia against naturalization was not without precedent before 1932. In 1909, led by future members of the 'Young Tunisians', large crowds amassed outside the Palarium in Tunis to protest against the proposed introduction of a law permitting Tunisian Jews to take French nationality. While a blow to the bey's authority, the judgment to allow Tunisian Jews to take French nationality and be subject to French courts arguably set the stage for the later articulation of Tunisian nationality and national identity along specifically Arabo-Islamic lines. However, it is worth noting that in spite of earlier moves to allow Tunisian Jews to become naturalized French citizens, this did not mean that Tunisian nationality automatically came to be defined along Islamic lines. Indeed, in an early manifesto of the nascent Destour entitled La Tunisie Martyre, published in January 1920, Tunisian nationality is specifically cast as independent of any religious considerations (El-Ghoul 2005: 202). What is more, the overwhelming majority of Tunisian Jews retained their Tunisian nationality despite changes to the law (Bessis 1981: 149). Whereas previous laws introduced in 1887, 1889, and 1910 had made it possible for some Tunisians to become naturalized French citizens, it was only in the laws of 1921 and 1923 that the policy of naturalization went 'on the offensive (Bessis 1987: 597)'. These laws made it easier for non-Tunisians to take French nationality but also loosened the required conditions for Tunisian Muslims to become naturalized French citizens. While certain nationalist figures railed against the decision, no instances of popular mobilization in opposition to the new law were seen and ' $[t]$ he mass of Tunisians remained generally indifferent to those who became naturalized French citizens (Jones 1977: 166)'. What is more, very few Tunisians ultimately came to adopt French nationality. From a high-water mark of 154 in 1927, in 1930 just thirteen adult Tunisian Muslims took French nationality and only five became naturalized French in both of the subsequent years (Bessis 1987: 603-4; Kraiem 1976: 255). Overall between 1921 and 1930, a total of just 1,016 Tunisian Muslims are said to have become French citizens (Bessis 1981: 149). ${ }^{5}$ 
Most of these came from the capital Tunis and the surrounding coastal regions of Tunisia, while inner Tunisia saw very few of its residents becoming French nationals (Kraiem 1987: 624). Furthermore, before the outbreak of the anti-naturalization campaign, it seems that French authorities had given up on the policy of encouraging Tunisians to seek French citizenship (ibid.: 629), and in the minds of many the Morinaud laws were 'unsuccessful and almost forgotten (Jones 1977: 165)'.

Against this backdrop, the outbreak, in 1933, of a mass campaign against naturalization becomes all the more perplexing and makes clear the need to pay close attention to the mechanisms underlying its development. The most frequently cited trigger for the subsequent wave of protests that made up the anti-naturalization campaign was the proposed burial in a Muslim cemetery of the president of the Bizerte chapter of the Ligue des Musulmans français de Tunisie (Ligue), Mohamed Chaâbane. The protests at this particular burial were likely rooted in local antipathies to Chaâbane himself as well as the organization he headed that was widely understood to be an active advocate of a policy of assimilation (Jones 1977: 168). There is also no real evidence of Destour Party involvement. Two weeks prior to this incident, a naturalized Muslim had been buried in Akouda where the Destour was better organized (ibid.). In 1931, too, we have records of two prominent figures in the Destour - Salah Farhat and Ahmed Essafi visiting the widow of a naturalized Muslim and arguing the importance of his body being buried in a Muslim cemetery since, although naturalized, 'he was first of all a Muslim (ibid.: 167)'.

Following the events in Bizerte, the only press outlets to carry the story were El Zohra, an otherwise unaligned newspaper with no nationalist sympathies, and L'Action Tunisienne (L'Action), a recently established newspaper that counted brothers Habib and Mohamed Bourguiba among its editorial staff (Jones 1977: 168-9). The question only reappeared a few months later when French Protectorate officials attempted to obtain, from the Maliki and Hanafi authorities in Tunis, a fatwa on the admissibility of the burial in Muslim cemeteries of naturalized Tunisian Muslims. While the Hanafi mufti Mohamed Ben Youssef ruled that such burials were permitted, the Maliki Tahar Ben Achour, rector at the influential Zaitouna mosque, made it clear that Muslims who had become naturalized French citizens could 'at best be considered sinful Muslims, and therefore able to be readmitted into the bosom of the Muslim religion only under the condition of having repented (Lewis 2014: 145)'. Given this disagreement, and the fact that 
the overwhelming majority of Tunisian Muslims adhered to the Maliki school, the decision was made not to publish the fatwa. Rumours, however, spread that Ben Achour had judged the burial of naturalized Muslims in Muslim cemeteries to be admissible and any reference to the sinfulness of naturalization and the specific condition of repentance was soon lost (Lewis 2014: 145-6). Meanwhile, leading figures in the Destour opposed the ruling on the basis that repentance could become a mere formality, and that such a ruling could unleash a 'flood of naturalizations' and 'lead to the eventual assimilation of Tunisia into French culture (Jones 1977: 170-1)'. On 8 April, Destour officials looked to use the bey's visit to Tunis on the fourth day of Eid al-Kabir to demonstrate publicly his subjects' opposition to the ruling. A crowd of around one thousand amassed outside Dar el-Bey shouting 'Down with naturalization and the naturalized!' and 'Long live the Bey' (Jones 1977: 171; Lewis 2014: 147). Finally, figures in the Destour organized for party cells in various areas of Tunisia to contribute to a petition and telegram-writing campaign directed at the bey and the religious authorities. These followed a set formula, demanding 'protection of religion and nationality' and expressing loyalty to the sovereign in the bey (Lewis 2014: 148). It is worth emphasizing that, in and through this episode, the militant sections of the Destour led by Habib Bourguiba arrogated to themselves the right to speak in the name of Islam, arguably over and above the influential Zaitouna establishment. Plans were formulated by the Destour to hoist effigies of Tahar Ben Achour in Western dress (Lewis 2014: 147) and a letter featured in L'Action asked if the real threat to Islam came from the apparently Europeaninfluenced nationalists or the religious establishment itself (El-Ghoul 2005: 200). Zaitouna students took an active part in the anti-naturalization protests, striking early on against their rector Tahar Ben Achour's ruling. Further, Lotfi Hajji suggests, during this conjuncture we see an important 'rapprochement' between the Bourguiba wing and Zaitouna students, many of whom would be present at the inauguration of the Neo-Destour a year later (Hajji 2011: 152).

The activities of the Destour leadership were thus highly influential in spreading information on the ruling and its apparent threat to Tunisian 'national identity'. Newspaper reports tell us that petitions had been received from Tunis, Sfax, Sousse, Methouia, El Kantara, Gafsa, Tozeur, Nefta, Feriana, Pont-du-Fahs, Tebourba, Béja, Mateur, Ras El-Djebel, and Bizerte (Jones 1977: 172). Further petitions are recorded as having been received from Bizerte, Kalaâ Kebira, Ferryville, M'Saken, Sidi Naija, Moknine, Monastir, Kairouan and Ksar-Hellal (Lewis 2014: 135, 
254, n.102). However, events seemed to outrun the Destour leadership and organized and less organized forms of protest activity ensued that, crucially, diffused outside of the capital in Tunis to numerous areas of southern and inner Tunisia. Since the establishment of the Protectorate more than fifty years prior, these areas had until this point never witnessed any episode of simultaneous oppositional mobilization against a policy of the French Protectorate. There is some evidence that striking students from the Zaitouna Mosque in Tunis returned to their homes in the interior of Tunisia armed with reports on the situation in Tunis that were communicated to awaiting crowds (Jones 1977: 172). Whatever the transmission channels, whether through the petition writing campaign or public oration of newspaper articles by so-called crieurs (El-Ghoul 2009: 255; Lewis 2014: 146), between 13 April and 22 April, demonstrations took place in all of Tozeur, Nefta, Gafsa, Sousse, Akouda, Sfax, M'Saken, Mahdia, Monastir, Moknine, Kalaâ Kebira, and Kairouan (Jones 1977: 172; Lewis 2014: 135, 255, n.110).

Reports of these protests point to the emergence and adoption of a particular repertoire. Protest would begin early in the morning and be joined by shopkeepers who had signaled their participation by closing (or failing to open) their shop stalls. Protesters would then march and present demands either outside the French contrôle civil or to a local qā'id (Kraiem 1987: 637; Lewis 2014: 149). The demonstrations would normally last until late morning and end either at a local Muslim cemetery or at the mosque where further protesters would join and the lați $f$ prayer would be recited (ibid.; Jones 1977: 172; Kraiem 1987: 637). ${ }^{6}$ While a particular contentious repertoire is discernible from accounts of these protests, other less organized and more transgressive forms of protest also emerged, as described below. What is more, everyday activities and matters of social conduct and ritual action came to be politicized as a result of this protest cycle. Naturalized Tunisians were barred from attending Friday prayers and reports suggest that the naturalized began to be turned down in marriage as a result of the widespread adoption of 'marriage boycotts' that, Abdelmajid Kraiem writes, 'made it almost impossible for the children of naturalized parents to find a partner in marriage (1987: 635-6)'. Business owners who had adopted French nationality were also readily identified and their shops boycotted (ibid.). In death, too, not only would the burial of the naturalized be opposed but also corpsewashers and prayer leaders would refuse to deliver the last rites to such newly identified 'renegades' while grave-diggers similarly withdrew their services (ibid.; Lewis 2014: 136). 
Most dramatic, however, were the direct and often bloody confrontations with police and armed forces staged outside Muslim cemeteries. On hearing of the news of the imminent or recent death of a naturalized Muslim, protesters would barricade the entrance to the cemetery and attempt to prevent the carrying out of the burial by force. An early instance of this took place on April 15 in the capital Tunis at Place Halfaouine. Moussa Ben Said, a naturalized French national had recently died and reports of his death were spread through the city. At first his house was surrounded in order to prevent the body from being taken to the cemetery. The crowd refused to move throughout the day and was only forcibly dispersed by assembled police and armed forces the following morning as tanks rolled through the Halfaouine and Bab Souika quarters of the city, giving it the 'appearance of a city under siege (Jones 1977: 172)'.

On 11 May, fearing that protest may spread even further afield, the French authorities announced that they would look into the possibility of creating separate cemeteries for naturalized Muslims, as demanded by some quarters of the nationalist press. Accompanying these concessions were renewed repressive measures, however. Already existing restrictions on Arabic-language newspapers were extended to French newspapers, the Destour was banned as a party and a decree enacted on 6 May giving the bey the power to place under house arrest anyone who could be suspected of 'propaganda activity of a political or religious nature or of any nature that could be seen to jeopardize general safety (Lejri 1974: 53)'. This, however, did not stop Bourguiba and his militant wing of the Destour from organizing further burial blockades. Seeing the success of the April protests in mobilizing large swathes of Tunisia in opposition, they searched for opportunities for further action. News reached them of a critically ill one-year-old son of naturalized court clerk Abdesselem Ben Ali Sayadi. Upon news of his death on 6 August, rocks were amassed by the entrance of the cemetery and his grave refilled overnight. ${ }^{7}$ By morning, a crowd hundreds strong had formed to prevent the burial from taking place and violent confrontations occurred between the protesters and armed forces after the civil controller called for backup leaving over forty people injured and one dead. The next day, the funeral of the killed protester drew a crowd of over one thousand and those arrested the day before were similarly treated as martyrs to the cause of the Tunisian nation (Lewis 2014: 152-3). Numerous similar incidents followed those in Monastir with 'the slightest rumor ... enough to trigger the assembly of a crowd to block burial (ibid.: 153)'. 


\section{Contention, National Imaginaries and Nationalist Politics}

We see, then, that in and through the anti-naturalization campaign a particular Islamic identity became salient as a driver of collective action and a category of collective identity. Through protest, Muslim identity and, by extension, Tunisian nationality was performed and enacted through highly visible and widely publicized forms of social action, thereby erecting a lasting and consequential boundary between Tunisians and non-Tunisians. What is more, this cycle of protests had a transformative impact on the landscape of elite-level politics, distinguishing Habib Bourguiba as the new and popular figurehead of Tunisian nationalism and defender of the Muslim faith, and effecting a tectonic shift in the tactical orientation of the nationalist movement that had seen itself overtaken by events on the ground.

As described above, before the outbreak of the anti-naturalization campaign, no significant popular opposition to the taking of French nationality had been witnessed in Tunisia. While it may be the case that the opportunity had not arisen for long-standing hostilities to naturalized Tunisians to be expressed up until this point, such a reading does not allow for the possibility that antipathies toward naturalized Tunisians were strengthened, reinforced or birthed in the context of protest itself. Indeed, it is likely that if these protests represented the expression of deep-seated and longstanding antipathies to naturalized Tunisians, then some form of popular opposition to naturalization would have manifested itself in the ten years since the Morinaud Laws were enacted. Since no such opposition was seen and, further, that just months prior to the events described above, burials of naturalized Muslims had gone ahead without any opposition, it would seem that we need to pay attention to the internal dynamics of protest itself as potentially productive of categories of identification that became salient and consequential as rubrics for collective and occasionally violent mobilization.

The emergence of a specifically Islamic identity as a salient marker of Tunisian national identity is best understood relationally. Since the naturalized Tunisian was no longer subject to the shari'a court and a Muslim civil code, Tunisian nationality could be yoked to notions of religious law and Muslim identity. However, it was only in and through protest that this constitutionally and legally enshrined element of Tunisian national identity came to constitute a target of claims and pretext for social action wherein the naturalized and non-naturalized, 
Muslim and non-Muslim, Tunisian and non-Tunisian came to be understood as counterposed to each other in a relation of mutual exclusion. Significantly, this distinction was embodied in other forms of social conduct when Tunisians began to boycott the businesses of the naturalized who had, as a result of this episode, ceased to be perceived as fellow co-religionists and co-nationals. In an indication of the strength of this boycotting activity, which extended to the rejection of the naturalized in marriage, the Ligue accepted, in 1936, the 'incompatibility' of Islam and French nationality, and asked to be allowed to 'reintegrate into the Tunisian nationality', citing their 'excommunication' from Islam as reason for their change of heart (Lewis 2014: 159).

The performative enactment through protest of this particular form of national identity was, in turn, reinforced by the particular repertoire adopted and the symbolically significant nature of protest sites themselves. In order to understand how the anti-naturalization campaign took on additional meaning as a specifically national struggle in the defence of a Tunisian nation, we must firstly look to the interactive dimensions of protest itself. As Mary Lewis herself notes, it was '[t]hanks to clashes with the police or army that attempts to block burials engendered, [that] the movement grew from one targeting French "meddling" in Islam on the specific issue of burial to one directed against French intervention in Tunisian life more generally (2014: 136)'. Indeed, while protest began as organized and peaceful, directed at local civil controllers and $q \bar{a}{ }^{\prime} i d s$ or taking the form of petition and telegram writing, the ensuing burial blockades led to open confrontations with the French police and armed forces during which Tunisian Muslims could be seen to be protecting not only religious sites but, by implication, 'sovereign Tunisian spaces (ibid.: 154)'. Furthermore, through the recitation of the lațif prayer and the ritual gathering outside mosques and cemeteries, the religiously defined bounds of Tunisian nationality and territory were reaffirmed. In other words, already sacred activities and spaces were 'resacralized (Sewell 2001: 66)' and invested with renewed significance in the context of protest itself. Not only were Tunisian Muslims defending their faith but, in and through the spatial and ritual dimensions of contentious practice, a nation and a form of Tunisian nationality that was thereby defined according to religious criteria and the Muslim 'identity' of the Tunisian nation.

Finally, and perhaps most importantly, the protests making up the anti-naturalization campaign can be seen as important in making imaginable categories of national-level identification. In the absence of an extensive oral historical record, of course, it is difficult to get 
inside the heads of protest participants and observers. However, we can speak in probabilistic terms of how the campaign came to be perceived and acquire meaning larger than that of opposition to a particular policy of the French protectorate. Here we should be aware of the symbolic significance of what Charles Tilly has elsewhere called 'public demonstrations of nationness (2002: 97)' through collective action not only in prompting recognition from political adversaries but also for participants' ability to 'imagine' themselves as part of larger national communities. Through petition-writing campaigns, the Destour made it possible for the entire nation, and not just those residing in Tunis and the Sahel, to participate simultaneously in making claims on behalf of a collectively defined people. One letter to L'Action published on 21 April is particularly suggestive of the constitutive role of collective action in producing sentiments of national identification, with the correspondent remarking on how, during the course of these protests, the 'entire Tunisian people [had] demonstrated, in quite astonishing fashion, ... a solidary and unified movement around religion and nationality ... the signs of a new era! (ElGhoul 2005: 197)'.

However, while instances of simultaneous mass-level contention may make possible the imagination of wider solidarities, the perceived significance of protest events is further conditioned by 'mediating processes through which people attribute meaning to events and interpret situations (Klandermans 1992: 77)'. During the anti-naturalization protests, nationalist print media was highly influential in spreading the news of petitions, confrontations and demonstrations and giving the impression of a nation-in-protest. The Destour party newspaper La Voix contained reports of the number and origin of petitions and telegrams that had been received from the various regions of Tunisia. Tellingly, one article was given the title 'A True Referendum Against Naturalization and the Treason of our Religious Leaders', thus lending to the sense in which this wave of oppositional activity constituted a statement of national opinion and a plebiscite of popular sentiment. Writing in L'Action after the events at Place Halfaouine and the sequence of protests across broad swathes of Tunisia, Habib Bourguiba declares that 'the voice of the people has made itself heard' and that 'the good people of Tunisia' have 'had enough and were looking for their opportunity ... to make it known that ... they were no longer under any illusions and would rise up with all their strength against any attack on their existence and personality (1954: 51-2)'. Attributing to the protests a significance wider than that of opposition 
to naturalization, Bourguiba writes that the 'death of a naturalized person ... presented the people with the opportunity to demonstrate their anger at an entire politics of disregard [toute une politique d'incompréhension] which had ... achieved the miracle of raising up nearly the whole country (ibid.: 52)'. Indeed, reporting of events related to the anti-naturalization protests were soon granted special sections under the headings of 'Voice of the Interior' [La voix de l'intérieur], and 'The Country Echo' [Échos du pays] (El-Ghoul 2005: 197), indicating how this struggle over burial rites had assumed wider significance as a struggle for the nation.

Crucially, the effects of this protest cycle were felt at an elite level, too. As Juliette Bessis notes, the anti-naturalization campaign 'served as a trigger for anti-colonial action and initiated a new and ascendant movement' with Habib Bourguiba emerging as a leader apart (1987: 607). While the Destour had played a definite role in the initial outbreak of protests in the form of petitionwriting and organized demonstrations, the movement itself outgrew this narrow repertoire, dividing opinion in the ranks of the nationalist movement. Bourguiba was not on the Executive Committee of the Destour at this point and his activities and writings in the newspaper L'Action had been the subject of some criticism from the old guard of the Party. Indeed, tensions between Bourguiba and the editorial team of Destour newspaper La Voix had been in evidence since 1931. At this time, it is worth noting, the Destour was particularly weak as a political force and, due both to repression and an ineffectual leadership, was left 'moribund (Anderson 1987: 166)'. As a result of mounting disagreements over the tone and positions to be taken in La Voix, Bourguiba and his radical associates from the Destour formed L'Action; a newspaper that, from the outset, exhibited a markedly more combative tone.

The tensions between these two wings of the Destour came to the fore during the antinaturalization campaign. In an article directed explicitly at Destour weekly La Voix du Peuple, L'Action lamented the complete lack of coverage in the nationalist press of the protests of 8 April and their failure to make clear the role of the Party in stoking these protests. If this is 'born of prudence', the author writes, 'it must be said that it is obviously misplaced' and if it somehow represents 'the height of strategy, then we must insist on making them see how [this attitude] has been overtaken by events on the ground (Lejri 1974: 51, n.81)'. During the antinaturalization campaign, Bourguiba also emerges as an increasingly prominent and influential member of the Destour. Indeed, it was Bourguiba's group that ultimately profited from the 
campaign by clearly staking out a position in support of popular mobilization. On 16 April, a day after the violent confrontations in Place Halfaouine, it was Habib and Mohamed Bourguiba who were received at the bey's palace in Hammam-Lif to discuss recent events and reassure the sovereign of the Tunisian people's loyalty (Jones 1977: 173). Most important, however, was that the editorial team of L'Action were invited to the Destour's Executive Committee. At a speech delivered at the party conference in Tunis on 12 May, Bourguiba, to loud applause, reportedly outlined the necessity for the leaders of the Destour to repudiate their now 'obsolete methods', and abandon their 'former programme, which has been overtaken by events and that no longer serves the deep aspirations of the people'. This meant, Bourguiba made clear, militating for independence for Tunisia through a unified party that was now 'profoundly reorganized around a new programme and upgraded methods (1954: 58-9)'. Habib Bourguiba and the rest of the editorial team of $L$ 'Action were invited the next day to the Executive Committee and, on 20 May, La Voix du Peuple published news of the Party's reorganisation, an outline of its demands, including a Tunisian parliament based on the principle of universal suffrage, and a statement of its mission declaring that the party's political activities 'aim at the liberation of the Tunisian people (Lejri 1974: 57)'.

This, however, did not stop the anciens of the Party from trying to undermine Bourguiba and his group. On the occasion of the Monastir protests later that year, Bourguiba's presence at the head of the delegation received by the bey's advisors was seen as an act of rank indiscipline by the senior members of the Party. Bourguiba was sanctioned and resigned from his position on the Executive Committee (Lejri 1974: 63-4). In response, from early 1934, Bourguiba set about visiting Destour party cells across the country, explaining his position and gauging support. On 2 March of that year, this culminated in the organization of an extraordinary congress of the Destour at Ksar-Hellal where he announced the dissolution of the old Executive Committee and their exclusion henceforth from the Party. In an indication of the profound impact of the antinaturalization campaign on the contours of nationalist politics, the anciens of the Destour then organized their own congress in an attempt to outbid Bourguiba by also calling for independence, saying that the 'evolution of the general political and economic situation has incited the Party to lead the people towards emancipation (Lejri 1974: 86, n.153)'. This move, however, failed to 
stymie the exodus of members from their ranks to what had by then become known as the NeoDestour.

Despite the subsequent repression of the Neo-Destour and the exile of its leaders, this series of events transformed the conduct and orientation of nationalist politics in Tunisia. From a position advocating reform within the bounds of the Bardo Treaty and a strategic orientation that operated at an elite level and saw popular mobilization as either dangerous or of limited value, the nationalist movement came to be built around the mobilization of mass popular support with the explicit aim of advancing the goal of independence. In a letter of November 1934 addressed to his brother Mohamed, Bourguiba writes that they must continue to encourage 'peaceful demonstrations across the entire territory of the Regency' and combine this with press propaganda and boycotts. 'Carried out simultaneously', Bourguiba writes, 'these actions cannot but have the effect of casting into relief the formidable reach of [the Neo-Destour], and of making the Tunisian people appear as a real nation with the defence of its interests at heart (Lejri 1974: 108-9 [emphasis added])'. The anti-naturalization campaign therefore engendered a marked shift in the strategic orientation of the nationalist movement in Tunisia, with the 'systematic use of public demonstrations', what Tilly refers to as 'We Are a Nation' performances $(1996,305)$, emerging as an 'essential element of political strategy (Jones 1977: 165)'. What had helped make this possible, though, were the networked ties and transmission lines that were another legacy of this contentious episode. As Bert Klandermans reminds us, when studying the construction and attribution of meaning in contentious episodes, we need also to pay attention to '[t]he bonds and networks that are the vehicles of these processes of social construction (1992: 78)'. Realizing the potency of mass mobilization both as a form of broadcasting grievances to wider areas and as a method of putting pressure on authorities and winning concessions, Bourguiba and his allies from L'Action set about forming party cells in rural regions hitherto neglected. This new cellular structure was what in subsequent months and years made 'possible the rapid mobilization of the masses that the party leaders regarded as their most powerful weapon (Perkins 2014: 101)'. Evidence of the effectiveness of this strategy can be seen early on. In September 1934, with the arrests of Bourguiba and several of his allies following a summer of strikes, boycotts and other protest, demonstrations in response to these measures were seen in all of Moknine, Tébourba, Menzel-Témime, El-Djem, Grombalia, Sfax, Kairouan, Mahdia, Smala-des-Souassis, Kalaâ Kebira, 
M'Saken, Sousse, Monastir, Djemmel, Gabès, Nabeul, Bizerte, Menzel-Bouzelfa, Bourdjine, Karkar, Lahrach and Gafsa (Lejri 1974: 99). Thus, through the anti-naturalization campaign, we see emerge new vehicles for the organization of protest and the expression of political dissent as well as a contentious repertoire operating on a national level.

\section{Conclusion}

The emergence of nationalism as a mass movement in Tunisia did not, of course, mean ultimate independence was foreordained. Indeed, it would be more than twenty years until Tunisia achieved formal independence. However, Islam would continue to occupy a contentious position within the politics of nationalism in Tunisia. The struggle between the two competing Neo-Destour factions of pan-Islamist Salah Ben Youssef and Bourguiba's reformist wing provided the pole around which nationalist politics was conducted in the years preceding and immediately following the proclamation of independence in 1956. Emerging as the ultimate victor was, of course, Habib Bourguiba who, as one time defender of Islam against a French menace and almujāhid al-akbar (Anderson 1987: 175), set about elaborating a unified justice system and a personal status code departing significantly from Islamic law while also suppressing the role of Islam at the level of political discourse, and abolishing the beylical monarchy (Charrad 2001: chap. 9).

We are therefore confronted, once again, with an illustration of the importance of paying close attention to contests over representation; that is, to contests over the 'meaning and boundaries of belonging to a nation (Aminzade 2013: 8)', and to struggles over the power to speak in the name of the nation. National identity and the forms that nationalism takes cannot, as the foregoing analysis shows, be understood according to the imaginings of nationalist intellectuals nor as phenomena readily analysable by reference to larger structural considerations. Further, when anti-colonial nationalism is the subject of study, we must attend to the particular configuration of the political field in colonial societies in order to understand how and why political contention could be articulated, channeled, and directed in certain ways. Indeed, understanding nationalism and the nation as categories of practice in an overall framework of contentious politics means investigating how, when, and why people come to speak and act in the name of a particular version of the nation. This means also paying attention to contentious events not simply as manifestations of underlying grievances or collectively held 
cultural categories but as, in themselves, constitutive of categories of collective identity and ways of 'imagining' the nation that may ultimately conduce to social action in the name of specifically nationalist causes.

The anti-naturalization campaign can be understood as one such event. Emerging, as it did, after more than fifty years of French Protectorate rule, this campaign found expression in and through demonstrations and forms of more openly trangressive contention that, significantly, centred on a question of religious and ritual import. In this, then, the anti-naturalization campaign as a (trans)formative event in the history of nationalist politics in Tunisia, sheds further light on the relationships between nationalism and religion and religion and contentious politics. In and through this campaign, Islam and the Muslim identity of the Tunisian nation came to constitute a salient boundary marker, idiom, and legitimate rubric for popular mobilization. As the first time that Tunisia had witnessed an instance of mass national-level mobilization in opposition to a particular policy of the French Protectorate, this campaign also had a lasting influence on the repertoire of contentious activities seen in subsequent years. Within the campaign, and as a result of its success, public demonstrations came to constitute a central tool of political struggle. What is more, we see over time the reorientation of such demonstrations toward specifically nationalist ends conducted under the aegis of the Neo-Destour, a party that would continue to struggle, and ultimately win, the right to speak in the name of the Tunisian nation.

\footnotetext{
1 These are criticisms relevant not only to Anderson's work but to a broader body of macroanalytic scholarship locating the emergence of nationalism in the 'modern' era. From a postcolonial perspective, the criticism has been that discussion of 'modular' national forms neglects the qualitatively different nature of anti-colonial nationalism (Chatterjee 1993). ${ }^{2}$ A particularly illustrative example can be found in Nicolas Ziadeh's (1962) account of nationalism's 'origins' in Tunisia.

3 This is an argument similarly advanced by Adria Lawrence in her penetrating (2013) account of nationalist mobilization in Morocco. The account offered here differs from Lawrence's account in showing how instances of mass-level resistance may occur in the absence of so-called 'disruptions to imperial authority' that she identifies as productive of nationalist mobilization (2013: 21ff.).

4 A Maghrebi equivalent of waqf ; that is, mortmain that is inalienable and the property of the religious authorities.

${ }^{5}$ Exact figures for the number of naturalizations over this period differ. See Lewis (2014: 245, n.9) for a list of sources and figures.

${ }^{6}$ In this there are obvious parallels with the protest repertoire in evidence during the Berber Dahir protests of 1930 in Morocco (Wyrtzen 2013). While falling outside the scope of this study, the potential transnational diffusion of protest repertoires as well as the coincidence of various events seen to threaten Islam (in the form of the Berber Dahir, the Eucharistic Congress in
} 
Carthage, and the suppression of the Association of Ulema in Algeria) across French-controlled North Africa, are worthwhile topics for further study.

${ }^{7}$ Further instances of tomb vandalism were recorded after this event. As Mary Lewis points out, tomb vandalism actually has a long history of use as a tactic of resistance in territorial disputes in the Maghreb (2014: 154). Parenthetically, it is worth noting that an attention to these precolonial or 'premodern' contentious repertoires may provide insights into the syncretism between local and more 'modular' forms of contention the emergence of which is generally imputed, after Tilly, to forms of state centralization and capital accumulation in the wake of colonial incursion (1995). 


\section{Bibliography}

Aminzade, R.R. 2013. Race, Nation, and Citizenship in Post-Colonial Africa: The Case of Tanzania. Cambridge: Cambridge University Press.

Anderson, B. 1991. Imagined Communities: Reflections on the Origin and Spread of Nationalism. London: Verso.

Anderson, L. 1987. The State and Social Transformation in Tunisia and Libya, 1830-1980. Princeton: Princeton University Press.

Barth, F. 1969. 'Introduction' in F. Barth (eds.), Ethnic Groups and Boundaries: The Social Organization of Cultural Difference. London: George Allen \& Unwin.

Beissinger, M. 1998. 'Nationalisms That Bark and Nationalisms That Bite: Ernest Gellner and the Substantiation of Nations' in J. Hall (eds.), The State of the Nation: Ernest Gellner and the Theory of Nationalism. Cambridge: Cambridge University Press.

Beissinger, M. 2002. Nationalist Mobilization and the Collapse of the Soviet State. Cambridge: Cambridge University Press.

Bessis, J. 1981. La Méditerranée fasciste: l'Italie mussolinienne et la Tunisie. Paris: Karthala.

Bessis, J. 1987. 'A propos de la question des naturalisations dans la Tunisie des années trente' in M. Chenoufi (eds.), Actes du 3e Séminaire sur l'histoire du Mouvement National: Les mouvements politiques et sociaux dans la Tunisie des années 1930. Tunis: Ministère de l'Éducation.

Bourguiba, H. 1954. La Tunisie et la France: vingt cinq ans de lutte pour une coopération libre. Paris: René Julliard.

Brown, L.C. 1964. 'Stages in the Process of Change' in C. Micaud (eds.), Tunisia: The Politics of Modernization. New York: Praeger.

Brubaker, R. 1996. Nationalism Reframed: Nationhood and the National Question in the New Europe. Cambridge: Cambridge University Press.

Brubaker, R. 2004. Ethnicity without Groups. Cambridge: Harvard University Press.

Burke III, E. 1998. 'Theorizing the Histories of Colonialism and Nationalism in the Arab Maghrib', Arab Studies Quarterly 20, 2: 5-19.

Calhoun, C. 1997. Nationalism. Minneapolis: University of Minnesota Press.

Charrad, M.M. 2001. States and Women's Rights: The Making of Postcolonial Tunisia, Algeria, and Morocco. Berkeley: University of California Press.

Chatterjee, P. 1993. The Nation and Its Fragments: Colonial and Postcolonial Histories. Princeton: Princeton University Press.

Cooper, F. 2005. Colonialism in Question: Theory, Knowledge, History. Berkeley: University of California Press.

Duara, P. 1995. Rescuing History From the Nation: Questioning Narratives of Modern China. Chicago: University of Chicago Press.

El-Ghoul, Y. 2005. 'Nationalité et religion: le refus de la naturalisation française en Tunisie entre les deux guerres', Revue d'histoire maghrébine 32, 120: 187-203. 
El-Ghoul, Y. 2009. Naturalisation et nationalisme en Tunisie de l'entre-deux-guerres. Tunis: Centre de Publication Universitaire.

Gellner, E. 1983. Nations and Nationalism. Ithaca: Cornell University Press.

Gelvin, J.L. 1998. Divided Loyalties: Nationalism and Mass Politics in Syria at the Close of Empire. Berkeley: University of California Press.

Hajji, L. 2011. Bourguiba et l'Islam: Le politique et le religieux. Tunis: Sud Éditions.

Hroch, M. 1985. Social Preconditions of National Revival in Europe: A Comparative Analysis of the Social Composition of Patriotic Groups among the Smaller European Nations. Cambridge:

Cambridge University Press.

Jones, R.E. 1977. 'The Naturalization Crisis of 1933: French Analysis and Tunisian Response', Revue d'histoire maghrébine 7-8, 165-78.

Julien, C-E. 1952. L'Afrique du Nord en marche: Nationalismes musulmans et souveraineté française. Paris: René Julliard.

Klandermans, B. 1992. 'The Social Construction of Protest and Multiorganizational Fields' in A.D. Morris and C.M. Mueller (eds.), Frontiers in Social Movement Theory. New Haven: Yale University Press.

Kraiem, M. 1976. Nationalisme et syndicalisme en Tunisie 1918-1929. Tunis: Union Générale Tunisienne du Travail.

Kraiem, A. 1987. 'L'Echec de la politique de naturalisation en Tunisie (1933/37)' in M. Chenoufi (eds.), Actes du 3e Séminaire sur l'histoire du Mouvement National: Les mouvements politiques et sociaux dans la Tunisie des années 1930. Tunis: Ministère de l'Éducation.

Lawrence, A.K. 2013. Imperial Rule and the Politics of Nationalism. Cambridge: Cambridge University Press.

Lejri, M-S. 1974. L'Évolution du mouvement national tunisien des origines à la deuxième guerre mondiale. Vol. 2. Tunis: Maison Tunisienne de L'Édition.

Lewis, M.D. 2009. 'Necropoles and Nationality: Land Rights, Burial Rites and the Development of Tunisian National Consciousness in the 1930s', Past and Present 205, 1: 105-41.

Lewis, M.D. 2014. Divided Rule: Sovereignty and Empire in French Tunisia, 1881-1938. Berkeley: University of California Press.

McAdam, D., Tarrow, S., and Tilly, C., 2001. Dynamics of Contention. Cambridge: Cambridge University Press.

McAdam, D., and Sewell, W.H. Jr. 2001. 'It's About Time: Temporality in the Study of Social Movements and Revolutions' in R.R. Aminzade, J.A. Goldstone, D. McAdam, E.J. Perry, W.H. Sewell Jr., S. Tarrow and C. Tilly (eds.), Silence and Voice in the Study of Contentious Politics. Cambridge: Cambridge University Press.

McCrone, D. 1998. The Sociology of Nationalism. London: Routledge.

McDougall, J. 2006. History and the Culture of Nationalism in Algeria. Cambridge: Cambridge University Press.

Perkins, K.J. 2014. A History of Modern Tunisia. 2nd edn. Cambridge: Cambridge University Press. 
Rivlin, B. 1952. 'The Tunisian Nationalist Movement: Four Decades of Evolution'. Middle East Journal 6, 2: 167-93.

Sammut, C. 1977. 'L'expression des symboles nationalistes par les premiers nationalistes tunisiens dans le contexte colonial', Revue d'histoire maghrébine 7-8: 201-20.

Sewell, W.H. Jr. 1996. 'Three Temporalities: Toward an Eventful Sociology' in T.J. McDonald (eds.), The Historic Turn in the Human Sciences. Ann Arbor: University of Michigan Press.

Sewell, William H. Jr., 2001, 'Space in Contentious Politics' in R.R. Aminzade, J.A. Goldstone, D. McAdam, E.J. Perry, W.H. Sewell Jr., S. Tarrow and C. Tilly (eds.), Silence and Voice in the Study of Contentious Politics. Cambridge: Cambridge University Press.

Tilly, C. 1995. Popular Contention in Great Britain, 1758-1834. Cambridge: Harvard University Press.

Tilly, C. 1996. 'The state of nationalism', Critical Review 10, 2: 299-306.

Tilly, C. 2002. Stories, Identities, and Political Change. Oxford: Rowman \& Littlefield.

Wimmer, A. 2013. Ethnic Boundary Making: Institutions, Power, Networks. Oxford: Oxford University Press.

Wyrtzen, J. 2013. 'Performing the nation in anti-colonial protest in interwar Morocco', Nations and Nationalism 19, 4: 615-634.

Wyrtzen, J. 2015. Making Morocco: Colonial Intervention and the Politics of Identity. Ithaca: Cornell University Press.

Ziadeh, N.A. 1962. Origins of Nationalism in Tunisia. Beirut: American University of Beirut. 